\title{
PR and the Media
}

\author{
A Collaborative Relationship?
}

\author{
LARSÅKE LARSSON
}

\begin{abstract}
What do the relations between the PR industry and the media look like? Are they traditional media-source or pressure group relations from the PR side? What is the outcome of these relations and how do they affect journalism and news selection? This study, based on interviews with both sides, identifies a close and continuous, though mostly one-sided, contact, in which PR actors steadily provide journalists and editors with instrumental news angles with regard to news management. While the former claim that they often succeed in planting their promotional ideas in newspapers and programmes, the latter mostly deny such a claim. However, admitting that the PR sphere does constitute a skilful news producer, journalists relate that, in times of decreased editorial resources, they are dependent on material from outside sources. A mutually dependent, exchange relation can thus be seen as a summarized picture of the PR-media relationship.
\end{abstract}

Keywords: public relations, media relations, PR-media, news management

\section{Introduction}

Public relations has become a significant and powerful industry, particularly in recent decades. This industry and its actors mainly work through the media to spread information, persuasion and opinions to the public on behalf of their clients. Publicity is the predominant goal. Networking, relation-building, news production and activities intended to be published in the media are thus part of the everyday work of PR agents such as information officers, PR consultants and spin-doctors.

The PR phenomenon needs to be examined and scrutinized as a new party and power in the democratic process. In recent years, some international studies have taken on this mission, but there is scope for more studies on different aspects of the phenomenon, not least in the Nordic countries.

This article is focused on the relation between the PR industry and the news media. The main themes and questions are: What characterizes the relation between the PR industry and the media or between PR agents and journalists? And, how do the characteristics of that relation affect journalism? The article starts by outlining some of the pertinent circumstances concerning the relation between the parties as well as their view of each other.

Suggesting that PR actors aim for a close and continuous relation with journalists in order to secure publicity payback is hardly controversial. The findings of this study support that assumption. The study is furthermore conducted under the assumption that 
news journalists have a sceptical approach to counterparts such as PR actors and that they are reluctant to publish such actors' material, fully in line with journalistic norms and professional journalistic work conduct. The outcome of this study shows that the first assumption about journalistic views is mainly correct, while the second is not.

\section{Theoretical Starting Points}

The news media are the most outstanding, common, and important channel for interest groups to get their messages out and influence their surroundings. Several researchers argue that a focus on media has, in fact, grown in importance to these agents, especially concerning those active on the scene of policy shaping in the broader sense. Manning (2001) means that media work has become a more central part of political activity in recent years; earlier, Franklin discussed 'packaging politics' and Blumler found that publicity advisers, public relations experts and campaign consultants "immerse journalists in what appears to be an increasingly manipulative opinion environment" (Blumler 1990:104). In addition, Cottle (2003) among others also notices an increased interest on the part of commercial groups in strategically mobilizing communicative power and attaining media space.

Studies of the relation between the PR industry and the news media show that PR actors and journalists often establish close relations in order to fulfil a mutual need (Davis 2002, see also, e.g., Allern 1997; Wien \& Lund 2001). The situation is similar to what research has shown about the relation between the media and institutional representatives such as politicians and government leaders (see, e.g. Tunstall 1970; Gans 1979; Ericson et al. 1987; Cook 1989; Larsson 1998).

The influence of the PR industry appears in many different shapes in daily life. It involves anything from traditional press conferences and press releases to various more or less successful long-term agenda-setting-related activities. Among other things, strategies for controlling the news agenda are based on producing and serving the media with material that promotes the instrumental purposes of the senders' interests. This type of media influence and strategies for controlling the news agenda are today often referred to by the concept news management (Pfetsch 1998).

Meanwhile, news material from sources outside the media may also be seen as a contribution to journalistic work and as a way of cutting costs. Observations in line with this point of view have made way for the theory of information subsidy, meaning "efforts by policy actors to increase the consumption of persuasive messages by reducing their costs", in the words of Gandy (1992:142). Several studies have shown that a reasonably large proportion of published articles originates from external sources - in fact, most of the studies conducted in relation to the subject area show that more than half of the studied published articles stem from material originating from outside sources (for an overview, see Cameron et al. 1997).

There is reason to argue that, in recent times, the theory of information subsidy has increased its relevance to the everyday journalism reality as a consequence of the financial and personnel cutbacks many news organizations have undergone. Some analysts claim that this type of contact and exchange has forced journalism to become increasingly dependent on, and more easily affected by, outside influences - a transformation of professional conduct that has resulted in a more alienated journalism (Blumler \& Gurevitch 1995; Bennett \& Mannheim 2001). According to Davis (2002), the cutbacks are one explanation of the fact that PR practitioners have come to strongly influence 
today's news agenda. He argues that the material they present has become extremely successful in passing itself off as 'real news', and thereby, to a great extent, PR people have "worked to erode the autonomy of journalists at the micro level" (Davis 2002:172). Other researchers follow this line:

(W)hat passes for news of politics is often an inextricable mixture of messages from different sources. Advertising, public relations, reports of opinion polls, and propaganda become mixed up in the news product along with facts and editorial opinions /... It certainly tends to undermine any simple faith in the reliability and independence of news (McQuail, Graber \& Norris 1998:253).

The view of media professionals as manipulated by representatives of the PR industry easily leads to questions concerning the media's position as the fourth estate. The media's role as a public utility in this regard might be discussed, according to Davis, as a consequence of the activities conducted by, among others, PR practitioners: "(T)he liberal description of the fourth estate media, based on an image of independent autonomous journalists seeking out news, has been severely undermined" (Davis 2002:173). In accordance, Street reasons that "journalists are the lapdogs of partial interests, not the watchdogs of the public interest" (Street 2001:146). However, contrary to this view, McNair (2000) argues that editorial staffs are fully capable of evaluating and disregarding material sent to them by the PR industry.

\section{Design and Method}

This article presents results from a study of the Swedish PR industry, its implications for society and its role in a democracy. The study is based on personal (in-depth) interviews with 64 professionals - information officers and PR consultants, on the one hand, and news journalists, on the other. The information officers work in-house in companies as well as governmental authorities; the consultants work at PR agencies or have their own firm. The journalists represent a broad spectrum in terms of their professional background; they are newspaper, radio, and television reporters and editors. The study is composed using a 'counter design', whereby the two parts - PR actors and journalists - are contrasted to each other to both facilitate comparison and serve as a check on their statements.

\section{Media and PR in Society}

The news media are the most prominent instrument for disseminating information in society. In the present study the interviewees claimed generally that the media have become an increasingly important stage for organizations' external communication. During the interview sessions, some of them also talked about the media as a prominent marketplace, as did this editor of a business magazine:

Today, the media are the most important marketplace - all important deals are settled in the media sphere /.../. And as everyone is squeezed together on the same media scene, it becomes very loud, very crowded and very short of oxygen. That's where the PR business comes in (Editor, business magazine).

The media, however, do not constitute a platform with actors of equal importance to PR practitioners. Rather, the media sphere appears as a media hierarchy. Typically, the 
largest radio and television stations along with the large national newspapers constitute the most important targets for PR activities. Within television, news programmes are especially sought after, followed by talk shows and entertainment programmes. For PR activities directed at the print media, the editorial and debate pages of the daily morning newspapers are essential targets. When it comes to activities such as product promotions and launches, trade magazines and other types of specialized press increase in ranking and become a high priority. For opinion-generating campaigns, regional and local media are also of interest. However, the latter types of media organizations pick up PR-related information mostly through news agencies, and thus their journalists experience little direct connection with PR agents.

The features of the relationship between PR agents and news journalists vary with the type of organization or consultancy they represent. Journalists often claim a sceptical approach to those representing commercial interests, as journalistic norms have long deemed textual product placement despicable. Representation in the interest of political organizations, on the other hand, sets a different tone because of these organizations' position as being fundamental to a democratic society and therefore considered to be legitimate opinion leaders. Their actions thus become "in the interest of the public". Public authorities are also by their nature obvious targets of media observation.

Between the corporate interest groups and the political groupings stands a middlecategory - the non-profit organizations. Non-profit organizations with a clear social ideology are often treated much like a party or public authority by the media. Furthermore, representatives of non-social ideology groupings often aim for publicity by trying to pass off their PR-activities as relevant to policy or community matters, regardless of whether this is actually the case. In other words, they attempt to move the characterization of a specific organization and its activities from the commercial sphere up to the societal/political one. In short, however, one can say that the media's perceived understanding of the potential social impact of the organizations the PR-agents represent largely determines the conditions for the relation. One editor used as an example the publicity demands of an organization defending the needs of disabled individuals:

It's an organization that uses us for its own purposes. But I see no problem as long as we make our own /journalistic/ judgement. We are aware of the fact that we are subject to persuasion, but I don't feel we avoid it as we would with attempts of product launches (Editor, regional newspaper).

\section{The Editorial Conditions}

The impact potential of the news media is of course a crucial factor in why journalists are a prioritized target of actions taken by the PR industry. However, there are at least two additional reasons for why media publicity is considered the best way to reach the public - and thereby to achieve a desired image and swing public opinion or parts of it in a favourable direction. First, publication in the media has a higher level of credibility than other communication channels do. Second, compared to advertising, media publicity is a cost-effective method.

It should be added that today's senders, whether they are professionals within an organization or hired consultants, find it fairly easy to get material published in newspapers. The prevailing conditions are the result of decreases in editorial staff in recent years and increasing demands for raised production goals for each journalist. "Today, 
we are so pressed by shrinking advertising revenue and diminishing circulation rates, that we try to save, we cut back wherever we can", said one editor. The work climate has created an increasingly stressful situation and resulted in less time for journalistic fieldwork, especially with regard to investigative efforts. That, in turn, has created an increased need for access to raw material from sources outside of the news desks. The senders - or agents promoting a specific interest - are well aware of the situation and use it consciously:

The everyday work of a journalist is very stressful/So/ they often consider contacts with PR agents as useful, if we practice serious work conduct and do no gold digging. Because we know exactly what journalists want (PR Consultant).

The information flow directed towards the editorial staff has thus allegedly increased, partly as a result of a much more flexible attitude towards promotion-related activities from the communications sector. In addition, those who aim to influence today know how to get through the editorial filters: "If you can bring in something that looks like news material, you can have a great deal of influence", as one journalist from a nationwide morning newspaper put it. During the interviews for this study, editorial staff members repeated the change in conditions and claimed it has brought about problems:

Today the news desks experience an in-flow of information never seen before, especially from the corporate sector. The input is overwhelming - if previously it was a stream, it's now more like a river /.../ Handling this flood of information is problematic, and there is a risk that journalists will get caught up in it and thereby decrease their ability to control the news agenda (Editor, regional newspaper).

This raises questions of whether the media may become dependent on this subsidy of information and material. Some journalists reflecting over their own work situation suggested there is a risk that reporters will become dependent on the influence of different activist experts. Even journalists with special beats sometimes experience a lack of knowledge, especially those within technical, medical and natural-science-related subject areas: "While we become too specialized we also become too dependent", said one public service TV journalist.

PR people call both openly and under cover to try to sell an idea to us. It's presented in a very feasible way /and/ then we're under extreme pressure to put together a paper for the next day /.../ They know our work situation and they know exactly what things to pull (Editor, evening newspaper).

By serving the media with news material, the activities of PR actors have caused their industry to move towards taking on the shape of a news desk located outside the media. In this study, one interviewed managing director of a PR consultancy in fact went so far as to suggest that PR firms "really are about being a satellite news desk".

\section{PR Agents' and Journalists' Perceptions of Each Other}

The PR experts' and journalists' views of each other differ a great deal. It seems that, in principle, many representatives of the PR industry have great respect for journalism and the media's role in society. They underline the media's obligation to review the PR sphere just as they expect journalists to do with other social phenomena. "There should be a strong journalism - and there is a strong belief /among us/ in the crucial 
role of journalism in society", said a junior consultant. One colleague stated that "it's extremely important to respect the media's integrity". At the same time, some of the PR actors in reality showed less respect for the media's professional task, as attempts to manipulate or steer the media in a favourable way seemed acceptable. Even among those who claimed a profound respect for the media, instrumental aims became discernible at times during the interviews.

Hardly any of the interviewed journalists expressed a corresponding respect for the PR agents. In principle, PR experts, especially consultants, were described as opponents, in line with the general normative thinking of journalism, which supports the view that PR people are to be kept at a distance. They are "my most important opponents," claimed one journalist of a national newspaper and continued by saying that the group has become so "unbelievably much more clever with what they do". As PR agents inevitably exist in the media professionals' work context, journalists are forced to respect them in the same matter as one has to respects an opponent:

I dislike the phenomenon /PR consultants/terribly. But I do realize that 'this is the way it is' and what am I to do? They're a part of today's society. And an influential part too (Editor, evening newspaper).

Journalists' mainly sceptical approach to PR is familiar to those working in the PR sphere. It is mirrored in the strategies of the latter - how to present material as well as how to present themselves in order to establish contact - and perhaps also in their professional self-image. Some of the interviewed consultants pointed to the fact that they are always straightforward in their contacts with the media and always explain whom or what interests they represent. Others commenting on the matter said, on the contrary, that they are careful not to give away that they are consultants, because then "they usually hang up the phone". Some also reasoned about the ambivalent approach they feel journalists have towards them:

Journalists have a type of love-hate approach towards PR agents. On the one hand, there's a contempt for /us/ for /our/ well-paid work, on the other hand, there's many times a use for our service in journalistic work (PR Consultant).

In their comments on PR agents, the interviewed journalists tended to group information officers and consultants. Both groups were viewed to have the same task and thus to be "of the same breed", as some journalists expressed themselves. The journalistic approach seems to be that there is actually no need for any PR agents. Meanwhile, in reality, the relation in itself may function differently depending on whether a PR person is placed inside or outside an organization - the latter case often making it more restrained. Still, some journalists claimed to make use of consultants in terms of information overviews and ideas for suitable sources. In addition, while they also fill a censoring role, information officers admittedly seem to be useful in negotiating contacts higher up in the organizations. Journalists, however, often find these officers annoying, as they want to speak with the person in charge; they do not to wish to get the answers "filtered through representatives one has to go by".

In this specific matter, journalists and PR consultants actually seem to agree. The latter claimed they should never be the voice of the organization they represent. Rather, their work is to organize the contact set up. It is always the client who should talk to the journalists, and "it would be absurd to have a consultant between the journalist and /the corporation/". Yet many journalists claimed that they are constantly subject to in- 
formation flows controlled by PR consultants. The discrepancy in the perception of the situation is likely to be a result of opposing relational perspectives on who controls the terms for the contact and in whose interest it is taken.

Journalists' mainly sceptical and negative approach to PR experts was accompanied by an attitude of rejection towards them when discussions during the interview sessions lead to the topic of what the relationship is actually like in reality. When the PR agents, on the other hand, voiced their opinion about the same reality, it was largely through opposite understandings of good and well-working relationships, common interests and sometimes collaboration.

\section{What does the Relation between PR Agents and Journalists Look Like?}

Perhaps the best answer to the question of what characterizes the relation between PR representatives and news journalists is one provided by an interviewed radio journalist: "it seems they have a better relation with me than I do with them". Overall, the interviewed PR agents claimed to have well-functioning relations with journalists and news desks. "We have a great relationship", was a typical attitude. None of the journalists expressed themselves in even a remotely similar manner. Very few spoke of such a relationship unless provoked to do so - it is obviously a sensitive topic from a normative perspective. Some journalists claimed to have no connection to PR people at all or that they avoid and reject such contact. Others had a more distanced approach to the relationship, saying that it constitutes "a role-play; they do their work and we do ours", or that the relation is completely neutral:

/The relationships/ are zero, neutral. They are neither positive nor negative. Not on my part. They sometimes bother me (Journalist, public service TV).

I have no relationships /with them/ at all actually. These very open-minded /consultants/ that call me ... my reaction is - no thanks, instantly. I want nothing at all to do with them (Editor, evening newspaper).

Rather than describing a relationship, most journalists did claim to be in contact - a less loaded word from a normative perspective - with PR agents. The contacts, mostly initiated by PR agents, may occur frequently, especially for news editors and reporters at newspapers with specialized beats. This generally consists of a daily information exchange, and in some cases, "certainly 10 to 15 calls a day". One trade press editor stated that "I can no longer have my cell phone turned on without it being bombarded with phone calls". The interviewed PR representatives generally agreed with the journalists on this. However, specific ideas about the perceived situation varied somewhat with seniority, as many of the more experienced communications strategists are more frequently in contact with the media. The perception of the information exchange also varied with the relevant topic and the client.

/I have/ a lot of contacts with journalists. /It consists of/ everything; the ones I email every day, talk to, have lunch with and the ones I get ideas from or talk to for updates. I give information to them as news in the same way as I advise clients (PR Consultant).

Establishing relations with the media is crucial to the success of a PR agent. It is decisive to create and maintain well-functioning relations with relevant editorial staff. The "fundamental objective is to make sure to build personal relationships with 'your' edito- 
rial staff", as one of them stated. Maintaining the relationship is a constantly ongoing process, where the aim is to "create a long-term relationship with journalists so they will know exactly where I stand in relation to them /and so they can trust/ that I will give them conclusive information". Meanwhile, PR agents cannot constantly pursue journalists' attention, as that would run the risk of straining the relationship.

Many /journalists/ feel that PR consultants are extremely annoying. It depends on whether you call them and terrorize them indiscriminately and try to shower them with information they don't want - then things can take a wrong turn. If you, on the other hand, respect them and try to be of help to them in their work, /you/ serve the purpose you're supposed to (PR Consultant).

Well-functioning relations with editorial staff are, of course, of crucial importance to PR agents who work with topics related to social issues and politics. However, as brand awareness has arisen as a pronounced goal for actions within the PR industry, these relations have become more important for those focusing on marketing-related communication. "It pertains to the whole thinking process in terms of brand awareness and recognition", as the CEO of one consultancy firm stated.

It is essential for a PR agent to not only make contact, but to establish 'the right' connections. This means aiming for media that fit clients' ideas or products in terms of content and audience. In addition, consultants have to identify individual journalists who might be interested in the specific topic they are seeking publicity for. This also means finding out what the editorial staff are momentarily interested in so as to prepare for consultation on suitable actions. The consultancies direct special resources to map out where to turn in order to maximize media coverage for exclusive news announcements and which individuals to contact for attaining best results. As one interviewed information officer put it, this is the ability and knowledge - or professionalism - that PR consultancies offer their clients.

The first thing is to make connections with the right people. To know which journalists write about which topic and who covers a particular industry. /Thus/ you conduct media analyses - analyse which journalists write about which type of questions (PR Consultant).

The relationship-building activities of the PR industry serve several purposes. Apart from, for example, aiming for publicity for one particular opinion project, a second purpose is to be recognised among the editorial staff as the consultancy - and as the individual - with the best in-depth and general knowledge of a certain topic. If such status is achieved, the hope is to lead journalists to initiate contact in their search for general knowledge or standpoints and comments when reporting on the topic. Several interviewed consultants claimed that they receive these types of phone calls fairly often, but none of the journalists participating in this study mentioned that type of contact. One of them said, however, "I try to use them as administrators in bookings /interviews with corporate representatives/ to facilitate my work". In other words, the consultant is used as an in-house spokesperson.

But there are consultants who do not focus at all on media relations or media influences, but concentrate on strategic and planning management. They are primarily senior and well-established consultants with their own businesses, which allow them to choose and direct their tasks much more freely: 
I have no media relations of that type to constantly try to affect. I don't call and nag at them all the time /.../ Besides, you destroy the relation by nagging all the time. It's not adult behaviour. But I can get things into papers when I need to (PR Consultant).

The information exchange between the two parties seldom consists of direct personal contacts in the sense of meetings, as often is the case for contacts between journalists and political or institutional representatives. Rather, the communicative exchange between journalists and PR agents largely concerns phone calls or e-mail correspondence - of which especially the latter has grown to be a very common method in recent times. "I have relations with the media /but/ I know no journalists, I have no personal relationships with them", stated one of the PR agents who was very representative of the collective. The interviewed journalists agreed more or less categorically with the statements and dismissed all talk about a colleague-like relationship. According to many journalists, however, one common tactic among PR agents is to "try to establish a friendly relationship even though the two parties have never met". In this lies the risk of becoming too friendly with each other; "the danger lies in friendship corruption", as one journalist at a business magazine put it. Meanwhile, as the most senior of the interviewed journalists stated, after years or perhaps decades of exchanging information "developing a pretty close relationship can't be avoided".

Agents belonging to the division of the PR industry that acts as lobbyists or works with lobby-like activities, however, do meet journalists in person, for example, at political party and labour union events. One consultant described how the work can involve spending a whole week at a party convention, registered as an 'observer':

It is very much a networking event to me - being around, getting to know people, finding new business opportunities and making new connections, interpreting the atmosphere and talking to representatives I know or get to know /.../ The most important thing is to observe the debate on general matters and matters of relevance to my clients' interests. Finding out what that makes the agenda and if there are any opponent representatives to my clients' interests. /And/ you might as well admit it's a lot about talking to journalists (PR Consultant).

A close and well-working relation with media professionals and an in-depth understanding of journalistic professionalism are, as we have seen, prerequisites of and a basic strategy for influencing experts in their aim to set the agenda. Although the attention to a client's interests is often obtained through contacts around specific campaigning, long-term success is best secured through on-going everyday relations and networking. Therefore, their work incorporates continuous updates and questioning and appearances at press conferences as well as attempts to spend time with journalists at different events that bring media professionals together - like seminars, breakfast meetings, entertainment happenings and sports-related events. Journalists, for their part, are well aware of the strategy:

/A/ clever PR person should network and talk to people around just about anything, that's how you establish a relation you can use later on. If you have established a relation you know the journalist will return to you to ask about more things /.../ We do the same thing. Journalists also network for the purpose of building a relation we can make use of in a longer perspective (Editor, business magazine). 
Personal connections are really important to their businesses. If they can produce something that fits into the media logic and its plot, it will result in coverage regardless of whether they have had lunch with /a journalist/ or not (Journalist, evening newspaper).

Common travels and dinner parties arranged by corporations - which used to be a common way of socializing - have largely disappeared, if one is to believe the interview responses of both parties. In general, today's editorial staff say they decline such offers, and corporations are allegedly restrictive about such activities. However, travels that include seminars, field trips and interview opportunities with powerful leaders still seem to occur, even if they occur less often today and have taken on a different form. Corporate management still orchestrates such events, but today the media organizations often seem to cover the journalists' expenditures. During one of the interview sessions, a former information officer remembered travelling in the US a couple of years ago:

Oh yes, journalists were on trips where we had seminars and further training for them along with visits to facilities. They didn't write about it then, but they might have written about it six months later, in total agreement with how we had laid out the situation. It's obvious there were elements of bribing or of an in-between zone (Information manager).

A particular type of relationship pertains to situations where both parties have journalistic backgrounds, i.e. when the PR expert is a former journalist and thereby perhaps a former colleague or at least a former member of the same profession as the approached journalist. Some journalists perceive this type of situation as especially troublesome, while to others it is completely unproblematic.

Some PR agents with a journalistic background also coach corporate leaders and other organization representatives on how to tackle the media. The interviewed journalists' opinions on this matter seem to split the professional group in two. Some dislike the phenomenon very much. They perceive it as training aimed to manipulate journalists, as a way to teach corporate leaders to "talk about hot topics and deliver half truths". The other half of the group consider it a good thing, as corporate representatives learn about the role of the media in society, so that they can master not "walking into traps or being fooled by a lie" and not being hesitant when "confronted with experienced journalists".

\section{A Legitimate Supply of Information or a Matter of Manipulative Influence?}

It is pretty much a non-negotiable fact that the interests of organizations continuously serve to provide the news media with material. More questionable is, however, whether the material consists of information that should rightfully be the subject of a news valuation process or whether the action attempts to influence and manipulate beyond the normative boundaries for journalists' information exchange with their sources?

Hardly any of the interviewed PR agents in this study talked about trying to influence the editorial work or control the journalistic news valuation process. Instead, they used expressions saying that they inform, tip and give suggestions, or perhaps the most common one - that they deliver ideas for news - as part of their work. They defended themselves in a more or less categorical way in response to the allegation that their professional task involves any kind of manipulation of the media. 
To the journalists, the question actually consists of two questions. The first one pertains to whether they themselves or their news desks are subject to influences from certain interest groups or their PR consultants chasing publicity. To this question the answer is no doubt yes; the flood of material and the amount of incoming information are generally viewed as activities aimed at influencing targeted media. The interviewed journalists showed clear standpoints in this matter:

You have to be careful with all messengers as they have a purpose, or at least they try to present you with a manipulated version of reality. They might well want to tell you the truth about their corporation as they feel that /their/ truth never gets any space $/ . . . /$ One thing is for certain and that is that it is never the whole truth (Editor, business magazine).

/They/ use the press all the time and the press constantly lets itself be used. It's part of the nature of the whole thing. /The interviewer: That's not what the journalism textbooks say?/ No, of course, they don't, but that's how it is (Journalist, national morning newspaper).

The other question concerns whether media organizations actually are affected in the sense that they publish what outside sources want them to. Among the journalists as a group, there seems to be an ambivalent attitude towards allegations that they allow themselves to be influenced by specific groups. Some journalists categorically said "I never allow myself to be affected" or that they do not fit the description of what they call 'bulletin' or 'megaphone' journalists. However, they did not feel that this rejecting attitude towards outside influence was always realized in full in reality. One senior journalist at a national morning daily pondered the matter and suggested that "no one would admit to having been manipulated, even if that was the case". A business magazine editor agreed that many journalists have a completely "mistaken self-image of being extremely independent and having a high level of integrity". Some talked about the matter in terms of being subconsciously affected, as "the implementation methods are very sophisticated":

Of course we are affected, it's pretty obvious. It's very easy to say 'I was invited to this meeting about a new pharmaceutical but I didn't go'. Then you can say 'I wasn't affected' but you were anyway (Journalist, public service radio).

There is a genuine suspicion towards that type of material. First, there's the old type of press releases that talk about new product launches /.../ We are pretty good at resisting being influenced by such things, occasionally it gives us something to publish /.../ Then there's another type, like /opinion and/ lobby material that isn't as easy to see through (Editor, regional newspaper).

From the perspective of the PR agents, the response to allegations of attempts to manipulate the media generally consists of references to the widely accepted view of journalistic decisiveness. It is up to the news desks to value the material they receive. The interviewees in this study maintained the perspective that the media live up to their gate-keeping role and that media professionals can handle the news valuation process in accordance with the prevailing norms of the journalistic profession. It was generally concluded that inherent in the editorial news valuation process is an assurance that external material not fit for publishing will be omitted. The journalists had, as would be expected, the same standpoint when asked whether the news valuation process functions as a filter for the material sent in by the PR industry, "I believe most do", said one television reporter in a manner representative of journalists as a professional group. 
I feel you should give most PR agents credit for being pretty clear on what works or doesn't work in journalism /.../ I can't remember having felt fooled, rather they tried to market the corporations in an honest way - of course with the hope that it would pay off in publicity (Journalist, national newspaper's business section).

Our task is not to dump material not worthy of reading on anyone /.../ We can't make up news stories, as the journalists can say no to them. If we want to get something in the paper we have to make sure it's good enough. It's their job to be sceptical towards us, and /.../ it's our task to make sure the material is good enough (PR Consultant).

The interviewees' perception that the news valuation process in journalism works well in accordance with journalistic norms became less clear-cut when the question was further defined during the interview sessions. The answer to whether PR agents succeed or fail in their attempts to create publicity is, according to the consultants, that they mostly succeed. "I feel we do pretty well, we mostly succeed, in 70-80 percent / of the cases/. However, in the 20 percent where we fail, we often fail big", in the words of one consultant.

However, the journalists' reactions varied much more. None of them responded with a straightforward yes. Starting with those who admitted that outside sources might have been somewhat successful in affecting them, the other end of the continuum contained those who were relatively certain they have never contributed to any 'successful' publicity outcome initiated by PR agents. Some said they have never been affected by outside pressure and completely denied outside influences, while several others readily mentioned situations in which sender organizations and PR bureaus have succeeded.

I believe they feel they pull off quite a lot because otherwise they wouldn't continue to call and send us stuff. So I guess they feel they have succeeded. I'm sure there are techniques that we don't see through. Naturally, it's something of a problem (Journalist, public service radio).

I can't remember that I've subconsciously fallen victim to a PR coup. I absolutely believe I haven't, I'm far too sceptical for that. At the same time, you can deliberately give in to a PR act /by/ using it in a report (Journalist, public service TV).

During interview sessions in which the question of influence was explored in more depth and discussed with reference to whether the journalists themselves would choose news topics suggested by PR agents, many believed they would not. To some, this question evoked reflections on how journalism perceives and communicates reality. That there are many ways to describe the same reality seems to be a well-known fact. "You have to realize that it is a myth that journalists can present some kind of objective truth", said one editor.

Many of the reporters and editors realized that a portion of news ideas originate from places other than their own news desks. Those who mentioned this claimed to have become increasingly aware of the fact that story ideas often come from outside sources such as organizational interests with specific objectives. The flood of material from the PR industry was in all instances perceived to be intense, to some even an annoying and irritating occurrence. One editor went so far as to say "most of what is published is commercial texts". In this case, it should be mentioned that the discussion largely pertained to adapted material - mostly research results and "well-done investigations", rather than traditional press releases and invitations to various events. 
The main part of today's journalism is based on some kind of advancement of some party - political parties, corporations, organizations, other actors /.../ In that sense, you could say that journalism today is actually mainly about reacting to outside impulses (Editor, business magazine).

I'm convinced that a greater part /of the news/ than we realize has an outside origin. We have ourselves at times tried to determine whether a particular idea started among the editorial staff, and the results are not uplifting. It may also be that someone has read an article on the debate page of DN/the largest Swedish national morning daily/, but where does that topic actually come from? (Editor, regional newspaper)

Meanwhile, some journalists claimed that PR agents are of assistance to them, even though their normative framework might depict them as opponents. In fact, some media professionals even added a positive and appreciative tone, as did the editor of a trade magazine who said: "I can get great ideas from PR consultants". Others spoke in a less enthusiastic tone, like the television reporter who admitted that "they make our work easier because they produce reports and reduce the time we spend on investigation - and that's pretty scary".

At times, the interview conversations on the theme of influence ended up almost describing a symbiosis - a situation of common needs and interests that constitute the exchange between PR agents and journalists. Several reporters expressed that "the aims may in some cases coincide" or that "the goal of a PR agent and our goal /.../ have coincided". A radio medical reporter gave the following example: "if it's about a symposium where you talk about a certain disease, you might say we have coinciding goals". Meanwhile, some journalists appeared to have difficulties speaking in terms of collaboration; they would rather say that "some research results we have published have probably coincided with someone's interest" (not the other way around, that someone's interests in publicity for a particular cause have been advanced by a news desk). One of Sweden's most recognized television journalists voiced the following thoughts on the influence of outside sources:

These PR agents, consultants and representatives of the powerful people in society are of value to us journalists, if you use them in the right way. You receive a lot of interesting material /from them/, you get an idea of what's going on. Then the objective is to not let yourself be controlled by them /.../ Of course we are subject to attempts at manipulation, but if you are somewhat independent and read up on the topic you're covering, you don't let yourself be manipulated, you use these people for your own purposes /.../ It's mutual usage (Journalist, TV journalist).

Discussions concerning a potentially wider range of sources for journalists and their ability to affect the journalistic work easily lead to reflections on news agenda-setting and the distribution of power in the relation between PR experts and the media. The interviewed PR agents claimed a number of cases in which they had set the agenda or at least made sure a topic was put on the agenda. At the same time, with some exceptions, they generally did not talk about any kind of power for themselves in the matter. One of them, though, reflected that "we are just another factor involved in affecting their news agenda and the power of journalism". A senior consultant expressed it differently, saying that PR activities "are of course aimed at reducing the influence of the media, because they are an uncontrollable factor, and management is all about gaining control”. 
With regard to the news production process, the interviewed journalists rejected suggestions that power can be located to any parties other than themselves. However, one editor with long experience was not convinced that journalists have all the power. Another editor reflected on agenda-setting from a much wider perspective: "We're aware that we're under pressure all the time and a popular target for their work. The question of who sets the agenda is central. It's very much a question of democratic values" (see Larsson 2005; 2006).

\section{Conclusions}

The news media are the main channel for disseminating information and controlling public opinion in favour of a particular group's interests. Accordingly, obtaining media publicity is an important aim of the PR industry. This fact leads to the almost trivial assumption that there is a connection between those who aim to influence the media and those who work in the news business.

The contacts between PR agents and journalists are extensive, in the sense that they are frequent, and mainly initiated by the former. Thus, journalists are constantly the designated targets of PR activities. According to both parties, personal relationships generally appear to be rare.

The views of the two parties are divided. PR agents commonly declare a high level of respect for the norms of journalistic conduct and for the media's role in a democratic society. They also view their relation with the media as well functioning. The journalists, on the other hand, generally express less respect for people working with PR and claim they do not have any established relations with them, even if they admit to often being approached by PR agents.

Furthermore their views on the outcome of this relation differ significantly. PR actors claim that they often succeed in their efforts to get publicity out of the news material produced. But, as they declare, there is no attempt to influence journalism; they just "deliver news ideas". Editors and journalists, on the other hand, agree that they frequently receive promotional materials from different organizations or consultants, but more or less resolutely state that they hardly ever consider using that type of material. In other words, the flow of PR material is no great problem in their eyes, as they are usually able to unmask the instrumental ends. In other words, the gatekeeper function works.

The PR actors' high level of respect for journalism, its role in society and its integrity should be contrasted to PR work practises that inevitably aim at providing publicity for a particular version of reality. Meanwhile, journalists' generally sceptical attitude towards PR activities should be measured against reality: the media clearly publish news stemming from PR material. Several studies show that the PR sphere is highly successful in achieving its aims, that is, the media do in fact publish material originating from this sphere to a quite great extent (Cameron et al. 1997).

Even if the contacts are said to be mostly one-sided - and mainly initiated by the PR sphere - they might well, in reality, constitute a two-way process. Through networking activities, the PR agents create awareness among journalists about their existence, which in turn increases their chances of being contacted by reporters in search of information. Thus, the PR industry always has suitable informative material ready for delivery. Some of the journalists interviewed in the present study stated that PR agents facilitate the journalistic task in this way. 
PR actions and activities within the frames of the PR industry result in an in-flow of news material and a constant marketing of ideas directed at the news desks. Simultaneously, editorial staffs are - and have been for some time now - subject to increasing restraints in personnel and resources, meaning less ability do conduct in-house research and a greater dependence on material sent from outside sources. This fact has been observed by the PR industry, and other outside sources that frequently approach the news desks with easily grasped and therefore tempting material, such as complete articles with a newsworthy angle and a content that appears truthful and objective, e.g., factual reports or public opinion polls.

\section{Discussion}

In many countries, the PR industry has undergone significant growth in recent decades. In Sweden today, the number of active communications experts is seven times that at the beginning of the 1990s (Larsson 2005). Through this significant growth, PR agents have established themselves as an important group alongside parties traditionally considered to be part of the democratic process. Close contacts between the PR industry and the news media can be observed.

Taking this reasoning one step further, the prevailing conditions mean that the PR industry and the media collaborate in line with the logic of traditional exchange theory - one party's need for media space is served by satisfying the other's need for material. This also means that, in many cases, the parties have become mutually dependent on each other and that they have developed a common interest in the relationship. The parties are thereby in collaboration, even if the relationship is perceived as unequal.

Theories on a collaborative relation lead to the assumption that the parties function in a common sphere, rather than representing two separate spheres. They exist in a common communication space in which the media constitute the central hub. This assumption is in line with Castells' thesis about informational politics in which market agents, journalists and policymakers all are part of the same sphere, the media sphere, which constitutes the framework for policymaking in a broader sense: "all politics must go through the media to affect decision-making" (Castells 1997/2004:375).

The media have always been courted by groups that have political agendas and that are, broadly speaking, in search of publicity for their activities. It seems the media have long been considered important in relation to image positioning and swinging public opinion in favourable way. The news desks, in their turn, may justify coverage of material from political groupings and government authorities with reference to its (and their) democratic role in society. But today, journalists increasingly accept influences from outside agents seeking public legitimacy for special interests in all sorts of areas. Within the journalistic culture, news is such an important element that there is reason to believe that a good story plot might be favoured over a critical approach to sources and reviews of submitted material. In addition, it does not seem farfetched to assume that journalism, like any other institution in society, has incorporated the market and promotion culture that dominates today's society.

The fact that so many of the interviewed journalists did not see any problems with the offensive from the PR industry is well worth considering. It seems relevant to question whether they simply accept the influential material or whether they perhaps do not realize, or cannot see through, the influence objectives of different group interests, occurring either through initiatives of the organizations themselves or through the consultants 
representing them. If the first case were to hold true, it would suggest that journalists accept the fact that these interests produce pseudo news, create pseudo events and utilize hidden messengers, or in other words, that they accept that the news material they receive often reflects constructed versions of reality. The reality of news desk conduct seems to be straying increasingly far from the norms and ideals of journalism (cf. Blumler \& Gurevitch 1995; Bennett \& Mannheim 2001; Davis 2002).

This means that today, to a relatively great extent, ideas for news are being developed outside the news desks and by, among others, PR agents within organizations and PR consultancies. This fact leads to an important question: What actually constitutes journalism and how should journalism be defined and explained? Is journalism what journalists at newspapers and TV/radio news rooms do or is it what is produced at editorial desks as well as external desks in the PR industry?

To close the discussion, news journalism appears to be having problems acting and reacting to the activities of the PR industry from an ethical, professional and practical standpoint. From an ethical point of view, journalists are at risk for overlooking demands of truthfulness and independent work conduct and thereby for becoming communication tools for financially strong interests. From a professional standpoint, journalists are at risk for experiencing diminishing public confidence. In everyday practice, journalists face the problem of resisting the sophisticated methods that are being targeted at them by experts in influencing opinions.

\section{References}

Allern, Sigurd (1997) Når kildene byr opp till dans. Oslo: Pax Forlag.

Bennett, Lance \& Manheim, Robert (2001) 'The Big Spin. Communication and the Transformation of Pluralist Democracy’, in Bennett \& Entman (ed.) Mediated Politics. Communication in The Future of Democracy. Cambridge University Press.

Blumler, Jay \& Gurevitch, Michael (1995) The Crisis of Public Communication. London: Routledge.

Blumler, Jay (1990) 'Elections, the Media ant the Modern Publicity Process', in Ferguson (ed.) Public Communication, The New Imperatives. London: Sage.

Cameron, Glen; Sallot, Lynne \& Curtin, Patricia (1997) 'Public Relations and the Production of News. A Critical Review and Theoretical Framework', in Burleson (ed.) Communication Yearbook 20. Thousand Oaks: Sage.

Castells, Manuel (1997/2004) The Information Age: Economy, Society and Culture. The Power of Identity, 2d ed. Oxford: Blackwell Publ.

Cook, Timothy (1989) Making Laws and Making News. Media Strategies in the US Houseof Representatives. Washington DC: The Brooking Institute.

Cottle, Simon (2003) Introduction, in Cottle (ed.) News, Public Relations and Power. London: Sage.

Davis, Aeron (2002) Public Relations Democracy: Public Relations, Politics and the Mass Media in Britain. Manchester University Press.

Ericson, Richard et.al. (1989) Negotiating Control. A study of News Sources. Milton Keynes/ London: Open University Press.

Franklin, Bob (1994). Packaging Politics. Political Communication in Britain's Media Democracy. London: Edward Arnold.

Gandy, Oscar (1992) Public Relations and Public Policy, in Toth \& Heath (ed.) Rhetorical and Critical Approaches to Public Relations. Hillsdale, J.J.: Lawrence Erlbaum.

Gans, Herbert (1979) Deciding What's News. New York: Pantheon.

Larsson, Larsåke (2006) Public Relations and Democracy. A Swedish Perspective, in L'Etang \& Pieczka (ed.) Public Relations. Critical Debates and Contemporary Problems. Mahway, New Jersey: Lawrence Erlbaum.

Larsson, Larsåke (2005) Opinionsmakarna. /The Opinion Makers. A Study of PR Actors, Journalists and Democracy/. Lund: Studentlitteratur.

Larsson, Larsåke (1998) Nyheter i samspel /News in co-operation/. Gothenburg: Göteborg University.

Manning, Paul (2001) News and News Sources. A Critical Introduction. London: Sage. 
McNair, Brian (2000) Journalism and Democracy. London: Routledge.

McQuail, Denis; Graber, Doris \& Norris, Pippa (1998) Conclusions. Challenges for Public Policy, in Graber, McQuail \& Norris (ed.) The Politics of News, The News of Politics. Washington: Congressional Quarterly.

Pfetsch, Barbara (1998) Government News Management, in Graber, McQuail \& Norris (ed.) The Politics of News, The News of Politics. Washington: Congressional Quarterly.

Street. John (2001) Mass media. Politics and Democracy. London: Palgrave.

Wien, Charlotte \& Lund, Anker Brink (2001) Flid, fedt og snyd - Kildens leg med Journalisten, I Nielsen, Mie Femø (ed.) Profil og offentlighet-public relations for viderekomne. Frederiksberg: Samfundslitteratur.

LARSÅKE LARSSON, Ph.d., Professor, School of Humanities, Education and Social Sciences, Örebro University, larsake.larsson@oru.se 